\title{
Murine hepatoma treatment with mature dendritic cells stimulated by Trichinella spiralis excretory/secretory products
}

\author{
Jing Ding, Xiaolei Liu, Bin Tang, Xue Bai, Yang Wang, Shicun Li, Jian Li, Mingyuan Liu, and Xuelin Wang*
}

Key Laboratory for Zoonoses Research, Ministry of Education, Institute of Zoonoses, College of Veterinary Medicine, Jilin University, OIE Collaborating Center on Foodborne Parasites in Asian-Pacific Region, Changchun 130062, P.R. China

Received 30 December 2019, Accepted 3 July 2020, Published online 21 July 2020

\begin{abstract}
Excretory/Secretory Products (ESPs) of the nematode Trichinella spiralis contain antitumor-active substances that inhibit tumor growth. Mature dendritic cells (DCs) play a critical role in the antitumor immunity of the organism. As pathogen-derived products, it ought to be discussed whether T. spiralis ESPs will reduce the antitumor effect of mature DCs from the host before it is applied to patients' tumors. Therefore, the aim of this work was to evaluate the immunological effect of DCs stimulated by T. spiralis ESPs in $\mathrm{H} 22$ tumor-bearing mice. H22 tumor model mice in this study were randomly divided into four groups according to the treatment: PBS control group, ESP group, DCs group, and DCs stimulated with $T$. spiralis ESP (ESP+DCs group). The antitumor effect was evaluated by tumor inhibition rate and cytokine detection using ELISA. The results showed significant inhibition in tumor growth in the ESP+DCs, DCs and ESP groups when compared with the PBS control group $(p<0.01, p<0.01$, and $p<0.05$, respectively). However, no significant difference was observed on tumor inhibition rates between the ESP+DCs and DCs groups. The decrease in IL-4, IL-6, and IL-10, and the increase in IFN- $\gamma$ between the DCs and ESP+DCs groups were also not significant. Therefore, DCs stimulated by ESP did not reduce the antitumor effect of mature DCs, which demonstrated that the $T$. spiralis ESP would not affect the antitumor effect of mature DCs by modulating the immune response of the host, and that ESPs are safe in antitumor immunology when applied in a tumor model mice.
\end{abstract}

Key words: Trichinella spiralis, excretory/secretory products, dendritic cells, H22.

Résumé - Traitement des hépatomes murins avec des cellules dendritiques mûres stimulées par des produits d'excrétion-sécrétion de Trichinella spiralis. Les produits d'excrétion-sécrétion (PES) du nématode Trichinella spiralis contiennent des substances actives antitumorales qui inhibent la croissance tumorale. Les cellules dendritiques (CD) mûres jouent un rôle essentiel dans l'immunité anti-tumorale de l'organisme. En tant que produits dérivés d'agents pathogènes, il convient de déterminer si les PES de $T$. spiralis réduisent l'effet antitumoral des CD mûrs de l'hôte, avant leur application aux tumeurs des patients. Par conséquent, l'objectif de ce travail était d'évaluer l'effet immunologique des CD stimulées par les PES de $T$. spiralis chez des souris porteuses de tumeurs H22. Les souris modèles à tumeurs H22 dans cette étude ont été réparties au hasard en quatre groupes selon le traitement : groupe témoin PBS, groupe PES, groupe CD et groupe CD stimulés par les PES de T. spiralis (CD+PES). L'effet antitumoral a été évalué par le taux d'inhibition des tumeurs et la détection des cytokines en utilisant un dosage ELISA. Les résultats ont montré une inhibition significative de la croissance tumorale dans les groupes CD+PES, CD et PES par rapport au groupe témoin PBS $(p<0,01, p<0,01$ et $p<0,05$, respectivement). Cependant, aucune différence significative n'a été observée sur le taux d'inhibition de la tumeur entre les groupes CD+PES et CD. La diminution de l'IL-4, de l'IL-6, de l'IL-10 et l'augmentation de l'IFN- $\gamma$ entre les groupes $\mathrm{CD}$ et CD+PES n'étaient pas non plus significatives. Ainsi, les CD stimulées par les PES n'ont pas réduit l'effet antitumoral des CD mûrs, ce qui a démontré que les PES de T. spiralis n'affectaient pas l'effet antitumoral des CD mûrs en modulant la réponse immunitaire de l'hôte et que les PES sont sûrs en immunologie antitumorale quand ils sont appliqués à des souris modèles tumorales.

\section{Introduction}

Trichinella spiralis was recognized for the first time in 1977 as a nematode that can negatively influence tumor growth

*Corresponding author: xuelin@jlu.edu.cn and prolong the lifespan of tumor-bearing mice [27]. Wang et al. demonstrated a strong antiproliferative and proapoptotic effect of $T$. spiralis antigens on two different cell lines (K562 and H7402) in vitro [45]. Even in the case of a very aggressive tumor such as melanoma, $T$. spiralis infection 
is effective not only in reducing tumor growth but also against malignant cell dissemination [16, 27].

A certain number of the studies available on the anti-tumor mechanism of $T$. spiralis focus on the immunomodulatory effects of its antigens. Kang revealed that CXCL9, CXCL10, IL-4, CXCL1, and CXCL13 expression may be related to tumor regression in mice with $T$. spiralis infection [16]. Trichinella spiralis antigens induce a significant decrease in serum IL-17, a significant increase in serum IL-10, and an increased percentage of splenic CD4+T-cells and intestinal FoxP3+ Treg cells as a defense against colon cancer in a murine model [9]. The immunomodulatory effect is based on the development and maintenance of Th2 response during $T$. spiralis infection and different from the anti-tumor immunomodulatory effects of mature dendritic cells (DCs) in the organism.

Mature DCs are correlated with an immune contexture characterized by TH1 polarization, infiltration by effectors cells ( $\mathrm{T}$ cells, NK cells, and plasma cells) and cytotoxic effector functions $[36,40]$. Mature DCs play a critical role in coordinating cellular interplay and in the anti-tumor immunity in host defense against pathogens and malignantly transformed cells $[10,17-19,25,30,32]$. Pathogen-derived products have the ability to induce the maturation of bone marrow-derived dendritic cells (BMDCs) [12]. ESPs of T. spiralis are a complex mixture of different molecules with different biological activities, which help in $T$. spiralis long-term survival by successfully evading and modulating host immunity [5]. The effect of $T$. spiralis on cells and molecules of the host's immune system is achieved through ESPs [34]. Trichinella spiralis ESPs contain antitumor-active substances that inhibit tumor growth [24, 44, 45]. ESPs of T. spiralis muscle larvae (ML) can induce the transformation of rat bone marrow-derived dendritic cells (BMDCs) to semi-matured status DCs [5]. Semi-matured DCs can be potentiated by either tolerogenic or pro-tumorigenic responses [8]. As pathogen-derived products, it ought to be discussed whether T. spiralis ESPs will reduce the antitumor effect of mature DCs from the host before it is applied to patients' tumors. However, a study on the immune safety of mature DCs stimulated by ESPs of $T$. spiralis against tumors is still lacking. Therefore, it is of utmost importance to evaluate the antitumor effect of $T$. spiralis ESPs.

\section{Materials and methods}

\section{Ethical standards}

Experimental animals used in this study were purchased from the Jilin University experimental animal center, China. To establish T. spiralis infection, ML were collected from infected experimental mice to ensure the maintenance of the life cycle system. Trichinella spiralis species were preserved in the Food-Borne Parasitology Laboratory of Key Laboratory for Zoonoses Research, Ministry of Education, Institute of Zoonoses, Jilin University, and genotyped by the OIE Collaborating Center on Foodborne Parasites in the Asian-Pacific Region. All experimental procedures were reviewed and approved by the Ethical Committee of Jilin University for the Care and Use of Laboratory Animals.

\section{Animals, parasites, cells, and antibodies}

Trichinella spiralis (ISS534) were obtained from specific pathogen-free female inbred Wistar rats $(220.0 \pm 20.0 \mathrm{~g})$, maintained by serial oral passage. Eight-week-old BALB/c and C57BL/6 male mice $(22.0 \pm 2.0 \mathrm{~g})$ were housed under proper care and specific pathogen-free conditions by the institutional guidelines. Wistar rats, $\mathrm{BALB} / \mathrm{c}$ and $\mathrm{C} 57 \mathrm{BL} / 6$ mice were purchased from Jilin University Experimental Animal Center (Jilin, China), with certificate No. 2016-0001 in conformity with SCXK (Jilin). The H22 hepatoma cell line was purchased from Bio-Rad Life Sciences Development Co., Ltd. (Beijing, China). FITC anti-mouse CD11c, PE Anti-Mouse MHC Class II (I-A), and $\mathrm{PE}$ anti-mouse CD86 were purchased from eBioscience (USA).

\section{Preparation of Trichinella spiralis antigen}

Trichinella spiralis ESPs were collected as previously described [20]. Briefly, T. spiralis ML were isolated from the muscle tissue of Wistar rats by the artificial digestion method. Wistar rats were infected with the isolated ML by intragastric administration to harvest adults (ADs) and newborn larvae (NBL) of T. spiralis. At 6 days post-infection (dpi), ADs of T. spiralis were harvested from the intestine of the infected Wistar rats, and the NBL were harvested from the culture medium after the AD were cultured in RPMI 1640 culture medium (Gibco, USA) overnight. The isolated ADs and NBL of $T$. spiralis were cultured in a Petri dish containing RPMI1640 culture medium without fetal bovine serum (FBS) and incubated at $37{ }^{\circ} \mathrm{C}$ in a $\mathrm{CO}_{2}$ incubator for $24 \mathrm{~h}$. The culture supernatant was collected by centrifugation, dialyzed, and concentrated. The protein concentration was measured by QuantiPro BCA Assay Kit (Sigma-Aldrich, USA) and the supernatant was stored at $-80{ }^{\circ} \mathrm{C}$ until use. The mixture of $\mathrm{ML}, \mathrm{AD}$, and NBL supernatant was concentrated and used as T. spiralis ESP in this experiment.

\section{Isolation and culture of mice bone-marrow- derived DCs}

Mouse BMDCs were obtained with an improved method that was previously described [22]. Briefly, bone marrow was collected from C57BL/6 mice, and erythrocytes were removed. BMDCs were cultured in RPMI 1640 medium supplemented with $10 \%$ fetal calf serum (FCS), $2 \mathrm{mM}$ L-glutamine, $1 \mathrm{mM}$ sodium pyruvate, $10 \mathrm{mM}$ HEPES, $50 \mu \mathrm{M}$ 2-mercaptoethanol (Sigma Aldrich, USA), and $50 \mathrm{U} / \mathrm{mL}$ gentamycin (Invitrogen, USA). On day 2, two-thirds of the original medium was replaced with fresh medium. On day 5, the floating cells were gently removed and the adherent cells were cultured with fresh medium containing $20 \mathrm{ng} / \mathrm{mL}$ GM-CSF, $20 \mathrm{ng} / \mathrm{mL}$ IL-4, and $10 \mathrm{ng} / \mathrm{mL}$ TNF- $\alpha$. On day 8 , the mature DCs were used for cell imaging experiments. Cells treated with phosphate-buffered saline (PBS) were used as a negative control $[22,39]$.

\section{Scanning Electron Microscopy (SEM) imaging}

Lab-Tek 4-well Chambered Cover glasses (Nunc, Thermo Fisher Scientific) were used for cell imaging experiments. 
Glass coverslips were coated with Poly-Lysine (Sigma-Aldrich, USA) $400 \mu \mathrm{g} / \mathrm{mL}$ in pyrogen-free water and incubated for $1 \mathrm{~h}$ at $37{ }^{\circ} \mathrm{C}$. A total amount of $3 \times 10^{5}$ mature DCs were seeded in a Lab-Tek 4-well Chamber with coated coverslips on the bottom, and incubated at $37^{\circ} \mathrm{C}$ for $5 \mathrm{~h}$. After cell attachment to the coverslips, the cells were washed three times in PBS, fixed in $2.5 \%$ glutaraldehyde (Sigma-Aldrich, USA) for $2 \mathrm{~h}$, then fixed in $2 \%$ osmium tetroxide (Sigma-Aldrich, USA) for $1 \mathrm{~h}$. The specimens were further rinsed in PBS, then dehydrated in increasing concentrations of ethanol $(10,20, \ldots$, 90,95 , and $100 \%$ ) for 10 min at each concentration, and finally air-dried overnight before analysis [3].

\section{FACS analysis}

Cells were incubated with FITC-CD11c, PE-CD86, and PE-MHC-II for $30 \mathrm{~min}$ at $4{ }^{\circ} \mathrm{C}$. All washing steps were performed in PBS or PBS supplemented with $2 \%$ FBS to avoid unspecific binding. Flow cytometry analyses were performed on a Coulter Epics XL flow cytometer (Beckman Coulter, Marseille, France) equipped with the analysis software Expo32 ADC (Beckman Coulter) [7].

\section{H22 cell culture}

The H22 mouse hepatoma cell line was purchased from the American Type Culture Collection (Rockville, MD, USA) and stored at $-80{ }^{\circ} \mathrm{C}$ after arrival. The $\mathrm{H} 22$ cells were cultured in DMEM supplemented with 10\% FBS (v/v), $100 \mathrm{U} / \mathrm{mL}$ penicillin G (Sigma-Aldrich, USA), and $100 \mu \mathrm{g} / \mathrm{mL}$ streptomycin (Sigma-Aldrich, USA). The cultures were maintained in a humidified incubator at $37{ }^{\circ} \mathrm{C}$ and $5 \% \mathrm{CO}_{2}$ [23].

\section{Model establishment, grouping, and administration methods}

Forty-eight C57BL/6 male mice (each with a bodyweight of $20 \pm 2 \mathrm{~g}$ ) were selected. The mice were intraperitoneally treated with $\mathrm{H} 22$ cells $\left(1 \times 10^{6}\right)$ under sterile conditions and were sacrificed after 5 days to collect ascites (the collected ascitic tumor fluid was thick and ivory in color, while the yellow or red ascitic fluid was discarded). Ascitic tumor fluid was then diluted with normal saline to adjust the cell concentration to $1 \times 10^{5} / \mathrm{mL}$. Each mouse was subcutaneously treated with $0.5 \mathrm{~mL}$ cell suspension in the right axilla of the forelimb. After inoculation, mice were randomly divided into four treatment groups: PBS control group, DCs, ESP and ESP+DCs therapy group ( $N=12$ per group). At $24 \mathrm{~h}$ after inoculation, the PBS control group was intraperitoneally treated with $2 \mathrm{~mL} / \mathrm{kg}$ PBS once a day; the ESP therapy group was intraperitoneally treated with $50 \mu \mathrm{g} / \mathrm{kg}$ ESP once every 7 days; the DCs therapy group was intraperitoneally treated with $6 \times 10^{6}$ mature DCs previously treated with PBS once every 7 days; the ESP+DCs therapy group was intraperitoneally treated with $6 \times 10^{6}$ mature DCs previously treated with $T$. spiralis ESPs (containing $50 \mu \mathrm{g} / \mathrm{mL}$ protein) once every 7 days. The administration period was concluded after 21 days. Mice were euthanized the day after the end of the experiment and the subcutaneous tumor was collected [28].

\section{Body and tumor weight measurement}

Mice body weight was measured every third day during the treatment period. At the same time points, the blood samples were collected from orbital sinus. The tumor was removed and weighed, and the tumor inhibition rate was calculated using the following formula [21, 31]:

$$
\begin{aligned}
\text { Inhibition rate }(\%)= & \left(1-\frac{\text { tumor weight of therapy group }}{\text { tumor weight of control group }}\right) \\
& \times 100 \%
\end{aligned}
$$

\section{ELISA}

A blood sample from each mouse of all groups was collected as described [1]. Blood was centrifuged at $300 \times g$ for $10 \mathrm{~min}$. The concentrations of the proinflammatory cytokines IL-4, IL-6, IL-10 and IFN- $\gamma$ in the serum were assessed by ELISA (R\&D Systems, USA), according to the manufacturer's recommended protocols (eBioscience, USA).

\section{Statistical analysis}

Statistical analysis was performed using SPSS 10.0 software (SPSS Inc., USA). Results were expressed as mean \pm $\mathrm{SD}$. Comparisons between the control and therapy groups were performed by one-way ANOVA. A value of $p<0.05$ was considered statistically significant.

\section{Results \\ SEM}

According to the morphology characterization of the typical mature DCs, the surface of DCs originating from bone marrowderived monocytes after 8 days of induction appeared rough and intact under SEM, therefore, these cells were considered mature (Figs. 1B, 1D). Conversely, DCs induced from monocytes after 6 days of induction did not have the typical morphology of mature DCs and were considered immature (Figs. 1A, 1C).

\section{Flow cytometric analysis of DC}

The ratio of $\mathrm{CD} 11 \mathrm{c}^{+}$monocytes after 8 days of induction was $60.45 \%$. The expression of the mature DC cell surface marker CD86 and MHCII family MHCII (I-A) was $51.67 \%$ and $81.68 \%$, respectively (Figs. 2A-2C), while the ratio of CD11c cells and the expression of CD86 and MHCII (I-A) in monocytes after 6 days of induction was $45.59 \%, 47.36 \%$, and $75.33 \%$, respectively (Figs. 2D-2F), which was higher than that of cells after 8 days of induction. The expression of CD11c, a specific surface marker of BMDCs, indicated that mouse bone marrow-derived monocytes cultured in vitro could be induced into DCs in relatively high purity.

\section{The general condition of $\mathrm{H} 22$ tumor-bearing mice}

H22 cells can develop into tumors after subcutaneous injection in mice (Fig. 3A). Mean body weight at day 27 was 

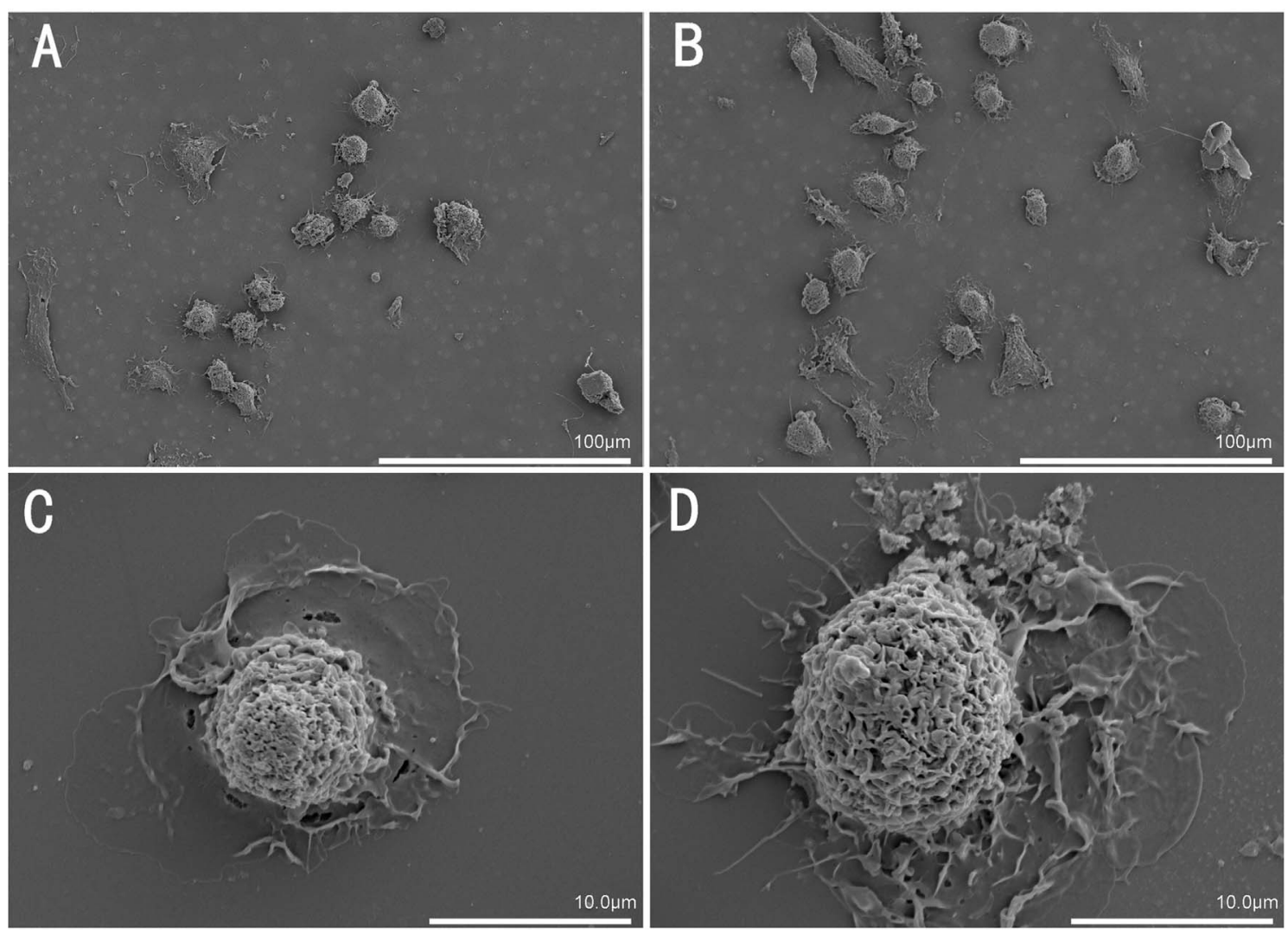

Figure 1. Bone marrow-derived dendritic cell (BMDC) morphology by scanning electron microscopy (SEM). (A) SEM image (500× magnification) of immature dendritic cells (DCs) formed by monocytes after 6 days of induction; (B) SEM image (500 $\times$ magnification) of mature DCs formed by monocytes after 8 days of induction; (C) SEM image (4K $\times$ magnification) of immature DCs formed by monocytes after 6 days of induction; (D) SEM image (4K× magnification) of mature DCs formed by monocytes after 8 days of induction.
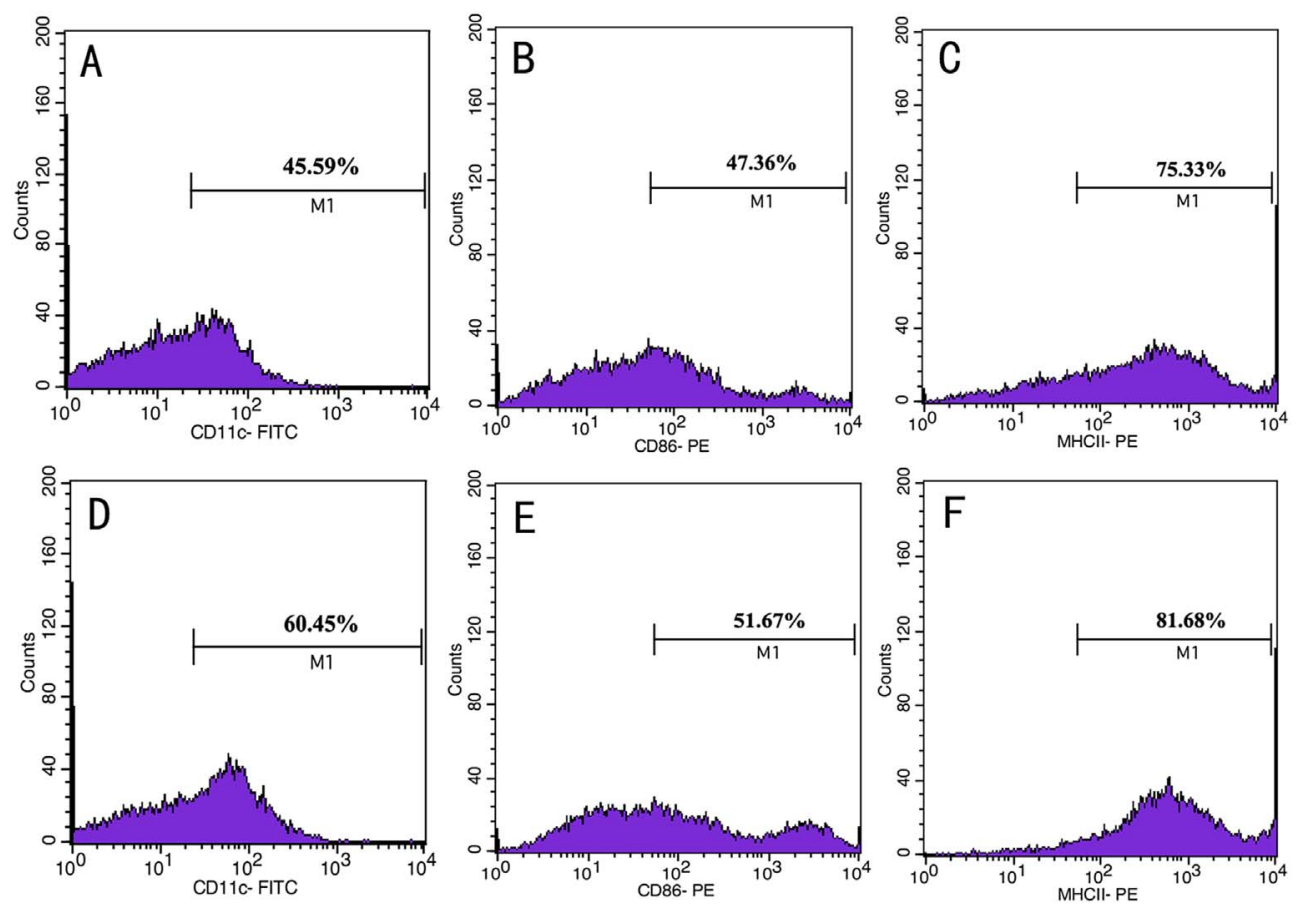

Figure 2. CD11c, CD86 and MHCII (I-A) expression in mature and immature dendritic cells (DCs). (A-C) CD11c, CD86 and MHCII (I-A) expression in immature DCs; (D-F) CD11c, CD86 and MHCII (I-A) expression in mature DCs. 

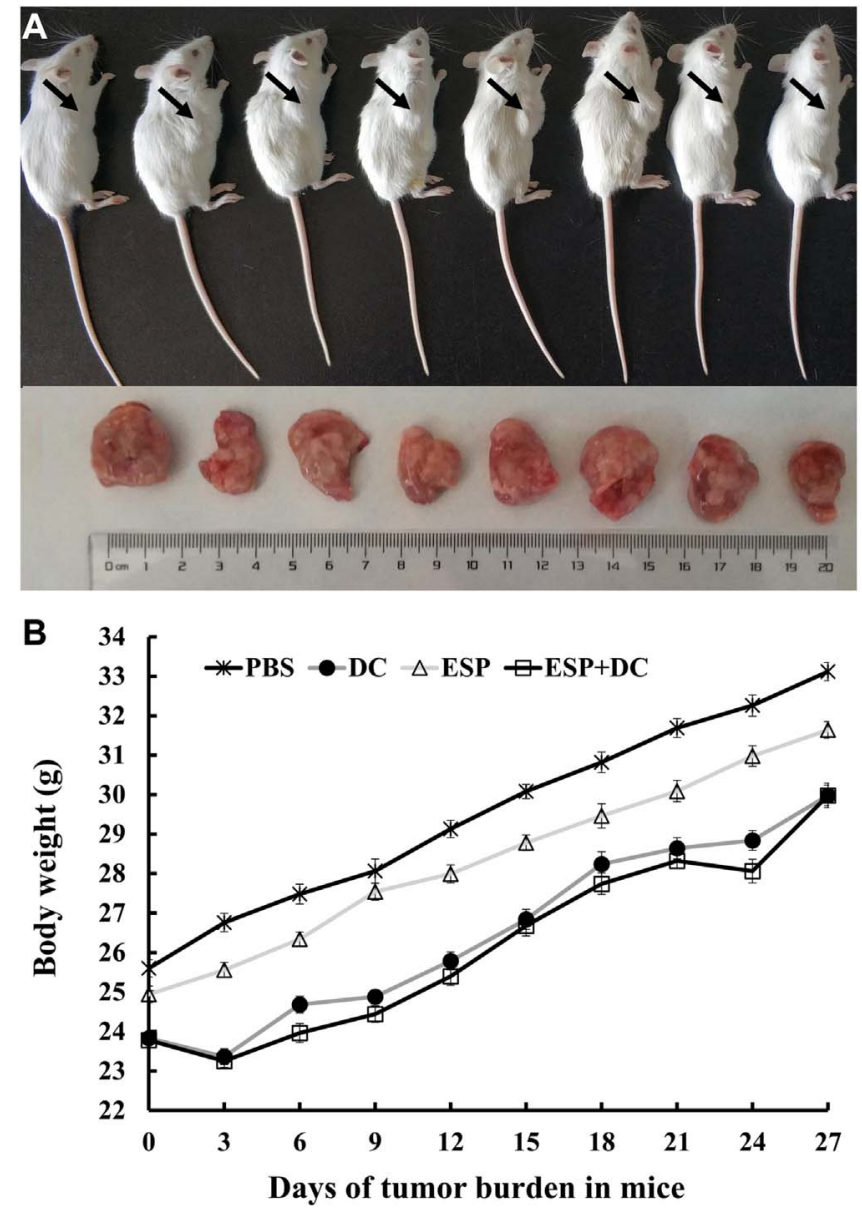

Figure 3. Body weight of each mice group. (A) H22 mouse hepatoma model; (B) Tumor growth curves of four H22-bearing mice groups with different stroma amounts and treated with PBS, excretory/secretory products (ESPs), immature dendritic cells (DCs) and ESP+DCs.

significantly decreased in the ESP+DCs and DCs group compared with the ESP and PBS groups. However, this weight variation was not significantly different between the mice treated with DCs and DCs stimulated with ESPs. In the PBS group, the mean body weight was significantly increased compared to of all the other three groups (Fig. 3B).

\section{Tumor growth inhibition}

Tumor inhibition rates in the ESP+DCs, DCs, and ESP groups were $48.82 \pm 5.88 \%, 48.57 \pm 6.06$, and $34.78 \pm$ $2.29 \%$, respectively. Significant inhibition in tumor growth was observed in the ESP+DCs, DCs and ESP groups when compared with the PBS group $(p<0.01, p<0.01$ and $p<0.05$, respectively). The inhibition rates in the ESP+DCs and DCs groups were significantly higher than those in the ESP group $(p<0.05)$ (Table 1$)$. The inhibition rate in the $\mathrm{ESP}+\mathrm{DCs}$ and DCs group was not significantly different.

\section{Cytokine production}

H22 hepatoma bearing mice treated with DCs and DCs stimulated by ESPs showed a decrease in IL-4, IL-6, or IL-10
Table 1. Tumor weights of BALB/c mice in each group and tumor inhibition rates.

\begin{tabular}{lcc}
\hline Group & Average tumor weight $/ \mathrm{g}$ & Inhibition rate $(\%)$ \\
\hline PBS & $3.70835 \pm 0.58923$ & \\
ESP & $2.41605 \pm 0.58923$ & $33.7405 \pm 0$ \\
DCs & $1.90088 \pm 0.58923$ & $47.6688 \pm 0$ \\
ESP+DCs & $1.8928 \mathrm{~s} \pm 0.5892$ & $47.948 \mathrm{~s} \pm 0$ \\
\hline
\end{tabular}

Results are expressed as mean \pm SD. $* p<0.05$ (ESP $v s$. PBS control group); $* * p<0.01$ (DCs and ESP+DCs vs. PBS control group); $* p<0.05$ (DCs and ESP+DCs $v s$. ESP).

compared with their levels in the PBS and ESP groups $(p<0.05)$. The treatment with DCs and DCs stimulated by ESPs resulted in significantly increased expression of IFN- $\gamma$ in comparison with $\mathrm{H} 22$ hepatoma bearing mice treated with PBS and ESPs only $(p<0.05)$. However, the reduction in IL-4, IL-6, IL-10, and the increase in IFN- $\gamma$ were not significantly different in the mice treated with DCs and DCs stimulated by ESP (Fig. 4).

\section{Discussion}

The antitumor effect of $T$. spiralis has been widely reported $[16,27,45]$. As a zoonotic nematode and foodborne parasite, T. spiralis infection leads to the suppression of the host immune response [13]. According to a previous study, T. spiralis antigens induce a mixed Th1/Th2 cytokine profile with a predominance of Th2 cytokines (IL-4, IL-6, and IL-10) increases $[6,35]$. In this study, ML, ADs, and NBL ESPs were used as $T$. spiralis antigens. The results obtained in this study indicated that $T$. spiralis antigens from all three life stages of the parasite contributed to the development and maintenance of Th2 response. However, T. spiralis ESP had the ability to inhibit tumor growth. ESPs of T. spiralis contain some functional proteins such as proteinases, proteinase inhibitors, heat shock proteins, glycosidases, protein kinases, endonucleases, thymidylate synthase, migration inhibitory factors, nucleotidemetabolizing enzymes, prosaposin and GM2 activator protein, enolase, superoxide dismutase, caveolin, and prolactin, with a potential role in the invasion of the enterocytes, and establishment or maintenance of the nurse cell system [48]. During nurse cell formation, muscle cell differentiation, proliferation, cell cycle, and apoptosis are regulated by mitochondriamediated factors from $T$. spiralis [2]. Trichinella spiralis infection causes a variety of changes in skeletal muscle cells and arrests the cell cycle of infected cells in G2/M for a long time [14]. A study showed that p53, a protein in ESPs, contributes to stagnation in the G1/G0 phase of the cell cycle [47]. Our hypothesis is that the antitumor effect of $T$. spiralis ESPs is not only due to the regulation of host immune response to Th2. If the immune response regulation has an effect on the antitumor immunity of the host, it impedes the antitumor application of $T$. spiralis ESPs. DCs are the most potent antigen-presenting cells in the host $[15,26]$ and mature cells can enhance the antitumor immune response [26]. CD11c is a specific antigen on the surface of mature DCs. During DCs maturation, the expressions of CD86 and MHC II increase, 
A
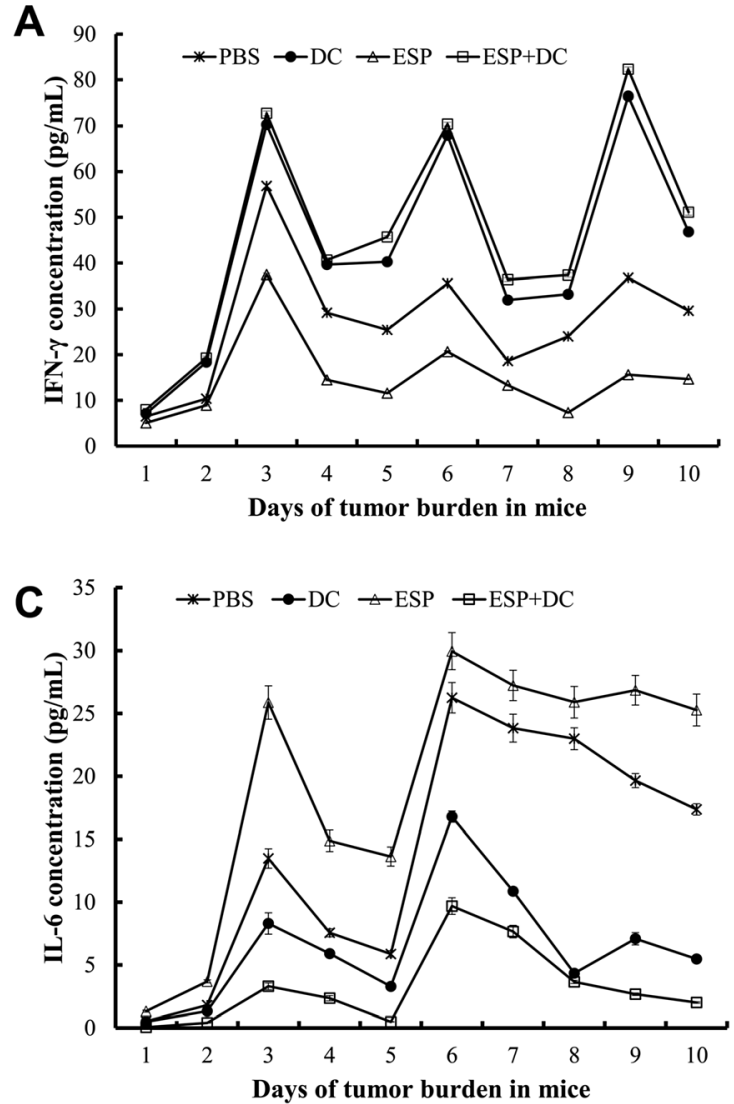
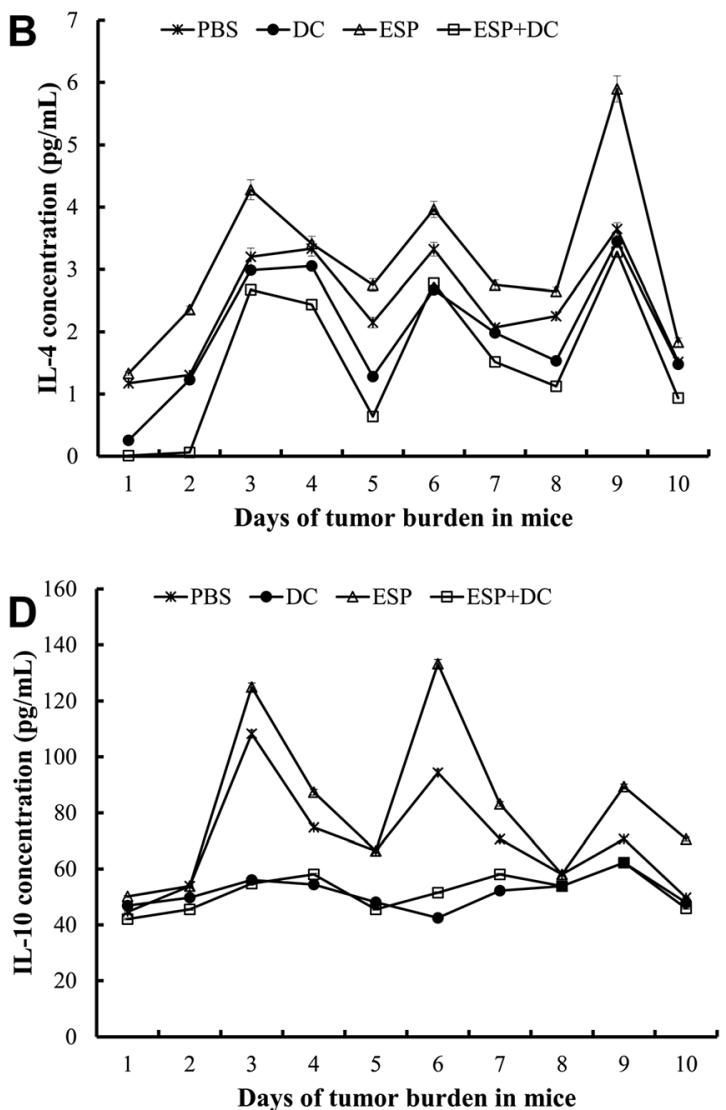

Figure 4. Cytokine content in serum of $\mathrm{H} 22$ hepatoma bearing mice treated with PBS, dendritic cells (DCs), excretory/secretory products (ESP) and DCs stimulated with ESPs. (A-D) IFN- $\gamma$, IL-4, IL-6 and IL-10 content in serum of H22 hepatoma bearing mice treated with PBS, DCs, ESP and DCs stimulated by ESPs during days 0-27.

allowing DCs to activate the immune system [4]. Specific surface markers including CD11c $\mathrm{c}^{+}, \mathrm{CD} 86$, and the MHCII family MHCII (I-A) were highly expressed in this work, indicating that mouse bone marrow-derived monocytes differentiated into mature DCs.

Mature DCs can strongly promote anticancer immunity and trigger Th1/Th17 cytokine secretion [8, 32, 33, 42, 46]. The close relationship between IL-4 and tumor progression has been investigated in several diseases [41, 42]. IL-6 overexpression is present in numerous cancer types, leading to the dysregulation of a plethora of cellular activities that generally promote tumor progression [37]. IL-10 is a classic anti-inflammatory cytokine that inhibits multiple DC functions, including maturation and production of proinflammatory cytokines [38]. In a cancer environment, IFN- $\gamma$ promotes anti-tumoral immunity through its direct activity on both tumor and immune cells [11, 29, 46]. Our results showed that the production of IL-4, IL-6, and IL-10 in H22 hepatoma bearing mice treated with DCs stimulated by ESPs was significantly reduced, while the expression of IFN- $\gamma$ was markedly increased, which was the opposite to the cytokine expression in the ESP group. However, no significant difference was observed in tumor inhibition rates and cytokine expression levels between the DCs group and the ESP+DCs group. Thus, our study suggested that ESPs had no immunological side effect to mature DCs in reducing tumor growth in the $\mathrm{H} 22$ hepatoma bearing mice.

Luo et al. suggested that $T$. spiralis ML ESPs induce apoptosis in $\mathrm{H} 446$ cells through a mitochondrial pathway, which may represent the antitumor mechanism [24]. ML ESPs, as parasitic products that are released during the chronic phase of infection, reduce the survival and slightly, but significantly increase the apoptosis of melanoma cells in vitro [43]. Our previous work also demonstrated that $T$. spiralis extracts induce apoptosis of K562 and H7402 cells, blocking their cell cycle in the $\mathrm{G} 1$ or $\mathrm{S}$ phase $[44,45]$.

Overall, our work demonstrated that the anti-tumor effect of T. spiralis did not affect the modulation of the immune response of mature DCs. Due to the complex immune response between the host and the parasite, the immunological safety of $T$. spiralis infection inducing antitumor effects needs further evaluation. Therefore, further studies that examine immunological changes are needed. Necrosis, apoptosis, and cell cycle change induced by ESPs of $T$. spiralis should not be neglected.

Acknowledgements. We would like to thank the OIE Collaborating Center on Foodborne Parasites in the Asian-Pacific Region for providing detailed instructions regarding foodborne parasites. 


\section{Financial support}

This work was funded by the grant from the National Key Research and Development Program of China (2016YFD0500707).

\section{Conflict of interest}

Authors declared no conflict of interests.

\section{References}

1. Aranzamendi C, Fransen F, Langelaar M, Franssen F, van der Ley P, van Putten JP, Rutten V, Pinelli E. 2012. Trichinella spiralis-secreted products modulate DC functionality and expand regulatory T cells in vitro. Parasite Immunology, 34(4), 210-223.

2. Boonmars T, Wu Z, Nagano I, Nakada T, Takahashi Y. 2004. Differences and similarities of nurse cells in cysts of Trichinella spiralis and T. pseudospiralis. Journal of Helminthology, 78(1), 7-16.

3. Bosch C, Masachs N, Exposito-Alonso D, Martínez A, Teixeira CM, Fernaud I, Pujadas L, Ulloa F, Comella JX, DeFelipe J, Merchán-Pérez A, Soriano E. 2016. Reelin regulates the maturation of dendritic spines, synaptogenesis and glial ensheathment of newborn granule cells. Cerebral Cortex, 26(11), 4282-4298.

4. Constantino J, Gomes C, Falcão A, Neves BM, Cruz MT. 2017. Dendritic cell-based immunotherapy: a basic review and recent advances. Journal of Immunology Research, 65(4), 798-810.

5. Cvetkovic J, Sofronic-Milosavljevic L, Ilic N, Gnjatovic M, Nagano I, Gruden-Movsesijan A. 2016. Immunomodulatory potential of particular Trichinella spiralis muscle larvae excretory-secretory components. International Journal for Parasitology, 46(13-14), 833-842.

6. Della Bella C, Benagiano M, De Gennaro M, Gomez-Morales MA, Ludovisi A, D'Elios S, Luchi S, Pozio E, D'Elios MM, Bruschi F. 2017. T-cell clones in human trichinellosis: Evidence for a mixed Th1/Th2 response. Parasite Immunology, 39(3), e12412.

7. Deluce-Kakwata-Nkor N, Lamendour L, Chabot V, Héraud A, Ivanovic Z, Halary F, Dehaut F, Velge-Roussel F. 2018. Differentiation of human dendritic cell subsets for immune tolerance induction. Transfusion Clinique et Biologique, 25(1), 90-95.

8. Dudek AM, Martin S, Garg AD, Agostinis P. 2013. Immature, semi-mature, and fully mature dendritic cells: toward a DCcancer cells interface that augments anticancer immunity. Frontiers in Immunology, 4, 438.

9. Eissa MM, Ismail CA, El-Azzouni MZ, Ghazy AA, Hadi MA. 2019. Immuno-therapeutic potential of Schistosoma mansoni and Trichinella spiralis antigens in a murine model of colon cancer. Investigational New Drugs, 37(1), 47-56.

10. Eyileten C, Majchrzak K, Pilch Z, Tonecka K, Mucha J, Taciak B, Ulewicz K, Witt K, Boffi A, Krol M, Rygiel TP. 2016. Immune cells in cancer therapy and drug delivery. Mediators of Inflammation, 2016, 5230219.

11. Gardner A, Ruffell B. 2016. Dendritic cells and cancer immunity. Trends in Immunology, 37(12), 855-865.

12. Ilic N, Colic M, Gruden-movsesijan A, Majstorovic I, Vasilev S, Sofronic-Milosavljevic L. 2008. Characterization of rat bone marrow dendritic cells initially primed by Trichinella spiralis antigens. Parasite Immunology, 30(9), 491-495.

13. Ilic N, Worthington JJ, Gruden-Movsesijan A, Travis MA, Sofronic-Milosavljevic L, Grencis RK. 2011. Trichinella spiralis antigens prime mixed Th1/Th2 response but do not induce de novo generation of Foxp3+ T cells in vitro. Parasite Immunology, 33(10), 572-582.

14. Jasmer DP. 1993. Trichinella spiralis infected skeletal muscle cells arrest in G2/M and cease muscle gene expression. Journal of Cell Biology, 121(4), 785-793.

15. Kang SA, Park MK, Park SK, Choi JH, Lee DI, Song SM, Yu HS. 2019. Adoptive transfer of Trichinella spiralis-activated macrophages can ameliorate both Th1- and Th2-activated inflammation in murine models. Scientific Reports, 9(1), 6547.

16. Kang YJ, Jo JO, Cho MK, Yu HS, Leem SH, Song KS, Ock MS, Cha HJ. 2013. Trichinella spiralis infection reduces tumor growth and metastasis of B16-F10 melanoma cells. Veterinary Parasitology, 196(1-2), 106-113.

17. Keller CW, Freigang S, Lünemann JD. 2017. Reciprocal crosstalk between dendritic cells and natural killer t cells: mechanisms and therapeutic potential. Frontiers in Immunology, 8, 570.

18. Kumar C, Kohli S, Bapsy PP, Vaid AK, Jain M, Attili VS, Sharan B. 2017. Immune modulation by dendritic-cell-based cancer vaccines. Journal of Biosciences, 42(1), 161-173.

19. Laurent F, Lacroix-Lamandé S. 2017. Innate immune responses play a key role in controlling infection of the intestinal epithelium by Cryptosporidium. International Journal for Parasitology, 47(12), 711-721.

20. Lee SH, Kim SS, Lee DH, Kim AR, Quan FS. 2016. Evaluation of protective efficacy induced by virus-like particles containing a Trichinella spiralis excretory-secretory (ES) protein in mice. Parasites \& Vectors, 9(1), 384.

21. Li T, LoRusso P, Maitland ML, Ou SH, Bahceci E, Ball HA, Park JW, Yuen G, Tolcher A. 2016. First-in-human, open-label dose-escalation and dose-expansion study of the safety, pharmacokinetics, and antitumor effects of an oral ALK inhibitor ASP3026 in patients with advanced solid tumors. Journal of Hematology \& Oncology, 9, 23.

22. Lin TJ, Liang WM, Hsiao PW, Pradeep MS, Wei WC, Lin HT, Yin SY, Yang NS. 2015. Rapamycin Promotes Mouse 4T1 Tumor metastasis that can be reversed by a dendritic cell-based vaccine. PLoS One, 10(10), e0138335.

23. Ling N, Zhou X, Ji Y, Li W, Ji C, Qi Z. 2017. Immuno-modulatory and cellular antioxidant activities of $\kappa$-selenocarrageenan in combination with Epirubicin in $\mathrm{H} 22$ hepatoma-bearing mice. Biomedicine \& Pharmacotherapy, 91, 132-137.

24. Luo J, Yu L, Xie G, Li D, Su M, Zhao X, Du L. 2017. Study on the mitochondrial apoptosis pathways of small cell lung cancer H446 cells induced by Trichinella spiralis muscle larvae ESPs. Parasitology, 144(6), 793-800.

25. Mbongue JC, Nieves HA, Torrez TW, Langridge WH. 2017. The role of dendritic cell maturation in the induction of insulindependent diabetes mellitus. Frontiers in Immunology, 8, 327.

26. Mizukoshi E, Kaneko S. 2019. Immune cell therapy for hepatocellular carcinoma. Journal of Hematology \& Oncology, 12(1), 52.

27. Molinari JA, Ebersole JL. 1977. Antineoplastic effects of longterm Trichinella spiralis infection on B-16 melanoma. International Archives of Allergy and Immunology, 55(1-6), 444-448.

28. Niu JX, Guo HP, Gan HM, Bao LD, Ren JJ. 2015. Effect of luteolin on gene expression in mouse $\mathrm{H} 22$ hepatoma cells. Genetics and Molecular Research, 14(4), 14448-14456.

29. Nocera NF, Lee MC, De La Cruz LM, Rosemblit C, Czerniecki BJ. 2016. Restoring lost anti-HER-2 Th1 immunity in breast cancer: a crucial role for th1 cytokines in therapy and prevention. Frontiers in Pharmacology, 7, 356.

30. Oth T, Vanderlocht J, Van Elssen CH, Bos GM, Germeraad WT. 2016. Pathogen-associated molecular patterns induced crosstalk between dendritic cells, $\mathrm{T}$ helper cells, and natural 
killer helper cells can improve dendritic cell vaccination. Mediators of Inflammation, 2016, 5740373.

31. Parasuraman S, Raveendran R, Kesavan R. 2010. Blood sample collection in small laboratory animals. Journal of Pharmacology \& Pharmacotherapeutics, 1(2), 87-93.

32. Said A, Weindl G. 2015. Regulation of dendritic cell function in inflammation. Journal of Immunology Research, 2015, 743169.

33. Schülke S. 2018. Induction of Interleukin-10 Producing dendritic cells as a tool to suppress allergen-specific $\mathrm{T}$ helper 2 responses. Frontiers in Immunology, 9, 455.

34. Sofronic-Milosavljevic L, Ilic N, Pinelli E, Gruden-Movsesijan A. 2015. Secretory products of Trichinella spiralis muscle larvae and immunomodulation: implication for autoimmune diseases, allergies, and malignancies. Journal of Immunology Research, 2015, 523875.

35. Song Y, Xu J, Wang X, Yang Y, Bai X, Pang J, Wang X, Yu M, Liu M, Liu X, Sun S. 2019. Regulation of host immune cells and cytokine production induced by Trichinella spiralis infection. Parasite, 26, 74.

36. Sun K, Wang L, Zhang Y. 2006. Dendritic cell as therapeutic vaccines against tumors and its role in therapy for hepatocellular carcinoma. Cellular \& Molecular Immunology, 3(3), 197-203.

37. Taher MY, Davies DM, Maher J. 2018. The role of the interleukin (IL)-6/IL-6 receptor axis in cancer. Biochemical Society Transactions, 46(6), 1449-1462.

38. Tang M, Diao J, Cattral MS. 2017. Molecular mechanisms involved in dendritic cell dysfunction in cancer. Cellular and Molecular Life Sciences, 74(5), 761-776.

39. Tomizawa M, Shinozaki F, Motoyoshi Y, Sugiyama T, Yamamoto S, Ishige N. 2017. Proliferation and motility of hepatocellular, pancreatic and gastric cancer cells grown in a medium without glucose and arginine, but with galactose and ornithine. Oncology Letters, 13(3), 1276-1280.

40. Truxova I, Kasikova L, Hensler M, Skapa P, Laco J, Pecen L, Belicova L, Praznovec I, Halaska MJ, Brtnicky T, Salkova E, Rob L, Kodet R, Goc J, Sautes-Fridman C, Fridman WH, Ryska A, Galluzzi L, Spisek R, Fucikova J. 2018. Mature dendritic cells correlate with favorable immune infiltrate and improved prognosis in ovarian carcinoma patients. Journal for ImmunoTherapy of Cancer, 6(1), 139.

41. Ul-Haq Z, Naz S, Mesaik MA. 2016. Interleukin-4 receptor signaling and its binding mechanism: A therapeutic insight from inhibitors tool box. Cytokine \& Growth Factor Reviews, 32, 3-15.

42. Van Acker HH, Versteven M, Lichtenegger FS, Roex G, Campillo-Davo D, Lion E, Subklewe M, Van Tendeloo VF, Berneman ZN, Anguille S. 2019. Dendritic cell-based immunotherapy of acute myeloid leukemia. Journal of Clinical Medicine, 8(5), 579.

43. Vasilev S, Ilic N, Gruden-Movsesijan A, Vasilijic S, Bosic M, Sofronic-Milosavljevic L. 2015. Necrosis and apoptosis in Trichinella spiralis-mediated tumour reduction. CentralEuropean Journal of Immunology, 40(1), 42-53.

44. Wang XL, Fu BQ, Yang SJ, Wu XP, Cui GZ, Liu MF, Zhao Y, Yu YL, Liu XY, Deng HK, Chen QJ, Liu MY. 2009. Trichinella spiralis - a potential anti-tumor agent. Veterinary Parasitology, 159(3-4), 249-252.

45. Wang XL, Liu MY, Sun SM, Liu XL, Yu L, Wang XR, Chu LX, Rosenthal B, Shi HN, Boireau P, Wang F, Zhao Y, Wu XP. 2013. An anti-tumor protein produced by Trichinella spiralis induces apoptosis in human hepatoma H7402 cells. Veterinary Parasitology, 194(2-4), 186-188.

46. Wylie B, Macri C, Mintern JD, Waithman J. 2019. Dendritic cells and cancer: from biology to therapeutic intervention. Cancers (Basel), 11(4), 521.

47. Zhang XH, Zhao C, Seleznev K, Song K, Manfredi JJ, Ma ZA. 2006. Disruption of G1-phase phospholipid turnover by inhibition of $\mathrm{Ca} 2+-$-independent phospholipase A2 induces a p53dependent cell-cycle arrest in G1 phase. Journal of Cell Science, 119(Pt 6), 1005-1015.

48. Zhang Z, Mao Y, Li D, Zhang Y, Li W, Jia H, Zheng J, Li L, Lu Y. 2016. High-level expression and characterization of two serine protease inhibitors from Trichinella spiralis. Veterinary Parasitology, 219, 34-39.

Cite this article as: Ding J, Liu X, Tang B, Bai X, Wang Y, Li S, Li J, Liu M \& Wang X. 2020. Murine hepatoma treatment with mature dendritic cells stimulated by Trichinella spiralis excretory/secretory products. Parasite 27, 47.

Reviews, articles and short notes may be submitted. Fields include, but are not limited to: general, medical and veterinary parasitology; morphology, including ultrastructure; parasite systematics, including entomology, acarology, helminthology and protistology, and molecular analyses; molecular biology and biochemistry; immunology of parasitic diseases; host-parasite relationships; ecology and life history of parasites; epidemiology; therapeutics; new diagnostic tools.

All papers in Parasite are published in English. Manuscripts should have a broad interest and must not have been published or submitted elsewhere. No limit is imposed on the length of manuscripts.

Parasite (open-access) continues Parasite (print and online editions, 1994-2012) and Annales de Parasitologie Humaine et Comparée (1923-1993) and is the official journal of the Société Française de Parasitologie. 